\title{
ANZLTA Conference Sermon: 2 Kings 23:13 and Luke 4:14-21
}

by Tom Frame

\author{
Tom Frame is Director of St Mark's National Theological \\ Centre in Canberra, and a Professor in the School of \\ Theology of Charles Sturt University.
}

$\mathrm{L}$ et me begin with a question (don't worry, it's rhetorical): why do so many religious institutions maintain libraries? (Perhaps it's not rhetorical). The answer is rather simple: because they believe books are important.

By why are books important? They are not attractive or colourful ornaments or for the most part made of valuable materials?

The importance of books is realised when they are read.

The extent of the investment in books suggests there is more to reading than connecting symbols on a page with their agreed meaning.

Through the reading of books, three things happen.

First, a person becomes conscious of the experiences and thoughts of others.

Second, a person joins the company of others and enters a conversation with them.

Third, this conversation has the capacity to entertain, enlighten and even to transform.

The Bible contains many references to the importance of preserved writings and of the significance of reading.

The rediscovery of the law book of the Temple in the reign of King Josiah recorded in 2Kings chapters 22 and 23 highlights the place and power of preserved writings within a community that honours the writers and the texts. The book found by Hilkiah effectively becomes the social, ethical and religious foundation of Judean society. Indeed, it shapes the future existence of the community and serves to unify them. They draw their identity from the book and commit themselves to its observance through a covenant.

The public reading of a portion of Isaiah's prophecy by Jesus in Nazareth recorded in Luke chapter 4 is a moment of enormous significance. It is a wellknown text and the source of great hope for an oppressed people. When Jesus chooses this text (Luke notes), reads it aloud and exclaims: 'today this scripture is fulfilled in your hearing', there is now no going back for him or his followers. In a few short and unadorned words read in the midst of a gathering of people, he has announced the inspiration and the intention of his ministry. No grand gestures; simply words read. 


\section{"I believe that}

\section{theological libraries}

provide not just

food for the mind

and fuel for the

intellect, they are

luscious markets

providing generous

nourishment for the

spirit."
But mere words? Symbols on a page that become sounds in the air?

Books are the repository of knowledge and wisdom. Texts deemed sacred by religious communities because they have divinely inspired authorship record accounts of God's presence in human affairs and God's dealings with women and men across the centuries. Claims for their divine inspiration are drawn from the timelessness of their observation and the universality of their insight. The writings of women and men deemed worthy of retention because they pointed to eternal verities or disclosed truths that have eluded others. Cherished words that become an indispensable resource to those seeking to understand the mystery of life and the human condition. How remarkable it is that the writings of people born decades, centuries and millennia before you and me ... are able to speak to us with clarity and force. Just words on a page? No.

When we abandon libraries and discourage reading: what are we doing? When we do those things:

1. we cut ourselves off from a rich inheritance of wise counsel and deprive ourselves of insights into our current situation;

2. we assert the primacy of the present and the irrelevance of the past;

3. we claim a cogency for our own perspectives that is usually exaggerated;

4. we impoverish our lives by declining the knowledge offered by the great cloud of witnesses whose testimony was thought worthy of preservation for others.

When a society closes libraries, burns books and prohibits reading, its fate has already been determined. It has become decadent. It is doomed. It will pass away unmourned and will not be missed. I do not think Australians, New Zealanders, Britons, Papua New Guineans, Solomon Islanders, Vanuatuans including their religious communities, pause long enough to reflect on what they are essentially saying in and through their libraries. Of course libraries are the source of entertainment and are used by people in their employment. But can I suggest we are saying much more than that, particularly in the establishment and maintenance of theological libraries. I believe that theological libraries provide not just food for the mind and fuel for the intellect, they are luscious markets providing generous nourishment for the spirit. Of course I go to our Library in Barton to find a book that I will enjoy or I will try to locate a pamphlet for an article I am writing. But I hope, too, that I will stumble (because I can't impose upon Susan and her staff all of the time) across a volume that might open my eyes to God's activity in the world, that might help me to draw nearer to God, thereby strengthening my faith, hope and love.

Perhaps like you, I can't imagine life without books or living without reading. And I remain grateful to the Librarian at West Wollongong Primary School in the early 1970s (I remember her 
"The wisdom of God and its reception or rejection by human society is encountered in theological libraries." name, Mrs Harman, such was her influence) and to those whose abilities and aptitudes have been devoted to the management and operation of libraries over the ensuing years.

I believe that the work of a librarian is a calling ... and it is a blessed one. Why? Because God blesses countless men and women through the work of librarians. I see it every day in my work and am reminded of its richness every time I even contemplate reducing library expenditure. (I may come to regret these words!). I am not sure if librarians routinely see their work in these terms. It doesn't matter if you don't. But you might hereafter and if you do, give thanks to God for this gift. But on behalf of those blessed by the devotion of librarians (and I think they are a particular kind of person), I convey our thanks and want to encourage you to continue in your calling. The wisdom of God and its reception or rejection by human society is encountered in theological libraries. Before that God this morning, we celebrate the access we have to writings both sacred and secular that enrich our lives and point us towards eternity. Amen. 